\title{
UTJECAJ POREZA NA DOBIT NA KRETANJE IZRAVNIH STRANIH ULAGANJA U ZEMLJAMA ČLANICAMA EUROPSKE UNIJE
}

\author{
Igor Banović \\ Univ. spec. oec., asistent u reviziji, Medicom d. o. o., Meštrovićeva 16, 51000 Rijeka, Hrvatska; \\ e-mail: igor.banovic@hotmail.com
}

\section{Helena Blažić}

Dr. sc., redoviti professor u trajnom zvanju, Sveučilište u Rijeci, Ekonomski fakultet, Ivana Filipovića 13,

51000 Rijeka, Hrvatska; e-mail: helena.blazic@efri.hr

\section{Saša Drezgić}

Dr. sc., izvanredni profesor, Sveučilište u Rijeci, Ekonomski fakultet, Ivana Filipovića 13, 51000 Rijeka, Hrvatska; e-mail: sasa.drezgic@efri.hr

\begin{abstract}
SAŽETAK
Većina raspoloživog kapitala nalazi se u posjedu pravnih osoba, odnosno poduzeća (najčešće multinacionalnih kompanija) sklonih ulaganju u širenje vlastitog poslovanja, što ne donosi samo dodatno uvećanje profita poduzeća, već indirektno utječe i na povećanje zaposlenosti, rast gospodarstva, razvoj domaćeg financijskog tržišta te općeniti napredak države. Zato države širom svijeta aktivno utječu na formiranje povoljnog poslovnog okruženja koje će imati učinak na povećan priliv izravnih stranih ulaganja (Foreign Direct Investments - FDI). Cilj ovog rada je uturditi utjecaj oporezivanja dobiti na privlačenje izravnih stranih ulaganja u zemljama članicama Europske unije. Statička panel analiza provedena je za razdoblje od 1998. do 2017. godine na 28 zemalja članica u cjelini, te posebno na starim članicama (EU 15) i novim članicama (EU13). Uz različite kontrolne varijable, kao nezavisna varijabla analizirane su različite stope poreza na dobit - zakonska (službena, nominalna) stopa poreza na dobit i efektivne (prosječna i granična) porezne stope u cilju ispitivanja stvarnog poreznog opterećenja trgovačkih društava i njihovog utjecaja na kretanje izravnih stranih ulaganja. Zaključeno je kako porez na dobit značajno utječe na kretanje izravnih stranih ulaganja trgovačkih društava u novim zemljama članicama Europske unije (koje karakterizira niže porezno opterećenje), ali ne kao primarni čimbenik, pri čemu se ističe društveni proizvod. U tom kontekstu najveći utjecaj ima efektivna prosječna porezna stopa.
\end{abstract}

Ključne riječi: porez na dobit, izravna strana ulaganja, EU 15, EU 13 


\section{UVOD}

Globalizacija je značajno doprinijela širenju poslovanja poduzeća izvan granica matičnih država, većoj mobilnosti kapitala te ekspanziji multinacionalnih kompanija u potrazi za novim tržištima i dodatnim uštedama. S obzirom da su investicije pokretač gospodarskog rasta i razvoja, države u želji pridobivanja većeg udjela stranog kapitala nastoje povećati svoju atraktivnost, između ostalog i nižim zakonskim stopama te raznim poreznim poticajima i olakšicama poreza na dobit.

Predmet istraživanja u ovom radu je porezna politika (na primjeru poreza na dobit) i njen utjecaj na privlačenje izravnih stranih ulaganja u zemljama Europske unije. Posebno je istaknuta uloga ne samo zakonskih poreznih stopa, već i poreznih olakšica i poticaja (čiji efekt dolazi do izražaja kroz tzv. efektivne porezne stope) $\mathrm{u}$ svrhu poticanja investicija.

Cilj rada je istražiti utjecaj oporezivanja dobiti poduzeća na privlačenje izravnih stranih ulaganja u zemljama članicama Europske unije u cjelini te posebno starim i novim članicama.

Temeljem navedenog, postavlja se hipoteza ovog rada - smanjenje poreznog opterećenja dobiti poduzeća predstavlja jedan od čimbenika odluke investitora u odabiru lokacije ulaganja kapitala. Smatra se da manja razina poreznog opterećenja dobiti predstavlja dodatni poticaj investitorima na odabir lokacije ulaganja, kada u uži izbor ulazi više zemalja sa sličnim pokazateljima poslovnog okruženja. $S$ obzirom da smanjenjem poreznog opterećenja dobiti poduzeća zemlje najčěćce nastoje nadoknaditi određene nedostatke na svom području i time povećati svoju konkurentnost, očekuje se kako porezna politika ima značajniju ulogu u privlačenju stranih investicija kod novih članica Europske unije. Navedeno se posebno očituje smanjenjem efektivnih poreznih stopa, iz kojih je vidljiva uloga poreznih olakšica i poticaja, što potvrđuje postojanje porezne konkurencije među zemljama članicama Europske unije.

\section{PREGLED LITERATURE}

Dosadašnja istraživanja uglavnom zastupaju tvrdnju kako porezna politika nije primarni činitelj pri donošenju odluka stranih investitora o ulaganju u određeno geografsko područje. Navedeno uglavnom vrijedi za istraživanja prošloga stoljeća, posebice do devedesetih godina (sinteza u npr. OECD, 2001:49-54; OECD, 2003:34)' dok već literatura s početka ovoga stoljeća

\footnotetext{
1 Navodimo najznačajnija pojedinačna starija istraživanja. Hartman (1984) je prvi analizirao utjecaj oporezivanja dobiti na kretanje izravnih stranih ulaganja u razdoblju od 1965. do 1979. godine, na prostoru SAD-a. Analiza je provedena sa stajališta ulaganja iz zadržane dobiti i novčanih transfera, a utvrđeno je kako postoji vrlo nizak, ali značajan utjecaj poreza na dobit na razinu priljeva stranih ulaganja. Boskin i Gale (1986) u svom su radu preispitali Hartmanove izračune, uz proširenje vremenske serije na razdoblje od 1956. do 1984. godine, te potvrdili njegov zaključak; uz naglasak o postojanju elastičnosti između izravnih stranih ulaganja i poreznih varijabli, koja je blago niža u odnosu na rezultate iz Hartmanovog istraživanja. Billington (1999) je ispitao faktore koji utječu na lociranje investicija u odabranim zemljama OECD-a, kroz priljev stranih ulaganja, u razdoblju od 1986. do 1993. godine. Djelovanje oporezivanja dobiti predstavljeno je zakonskom poreznom stopom, dok njeno smanjenje prikazuje nizak, ali pozitivan utjecaj na povećanje izravnih stranih ulaganja. Od ostalih, pomoćnih varijabli, posebno se ističe visok utjecaj pokazatelja veličine tržišta, odnosno bruto domaćeg proizvoda. Gropp i Kostial (2000) svoju su analizu usredotočili na razdoblje od 1988. do 1997. godine, u odabranim zemljama OECD-a, te također potvrdili postojanje niske i negativne veze između poreza na dobit i izravnih stranih ulaganja. Njihovo istraživanje je specifično s obzirom da osim utjecaja zakonske porezne stope uzima u obzir i utjecaj razine prihoda od poreza na dobit, uz isticanje postojanje porezne konkurencije među analiziranim zemljama.
} 
ukazuje da porezi (stope i poticaji poreza na dobit) postaju sve značajniji (npr. OECD, 2001:5560; OECD, 2003:34; de Mooij, Ederveen, 2003; Morisset, 2003:1, Gorter, Parikh, 2003).

Novija istraživanja također uglavnom ističu kako porezna politika (izražena najčešće kroz porez na dobit) ima veće značenje kod privlačenja stranih ulagača, posebno u novim zemljama članicama Europske unije. U nastavku su prikazana i neka istraživanja koja se odnose samo na Hrvatsku.

Carnstensen (2003) u svojoj dinamičkoj panel analizi za zemlje Srednje i Istočne Europe u razdoblju od 1993. do 1999. ističe statistički značajan utjecaj tradicionalnih lokacijskih varijabli na izravne strane investicije, među kojima i negativan utjecaj zakonske stope poreza na dobit na izravne strane investicije, kako kratkoročno, tako i dugoročno.

Jovančević (2003) istražuje izravna strana ulaganja u Hrvatskoj s aspekta percepcije menadžera, pri čemu se uzimaju u obzir razni elementi, uključivo i porezne. Menadžeri manjih poduzeća koja posluju u Hrvatskoj smatraju da bi daljnje sniženje stope poreza na dobit pomoglo u privlačenju izravnih stranih ulaganja. ${ }^{2}$ Slična kasnija istraživanja u Hrvatskoj provode Pavlović et al. (2013) anketirajući manje skupine menadžera. Tako u trinaest velikih hrvatskih poduzeća traže od njihovih menadžera da izaberu „tri najvažnija čimbenika, od mogućih deset koja smatraju bitnim za donošenje odluke o izravnom ulaganju u neku inozemnu lokaciju. Idućim istraživanjem anketiraju jedanaest vodećih inozemnih poduzeća u Hrvatskoj tj. njihove menadžere na isti način kako bi utvrdili njihove motive ulaganja u Hrvatsku. Umjesto poreza na dobit koristi se šira varijabla „visina poreza“, koja je rangirana na četvrtom mjestu u oba istraživanja. ${ }^{3}$

Wijeweera, Dollery i Clark (2007) ispitali su utjecaj oporezivanja dobiti na izravna strana ulaganja u SAD-u, koja proizlaze od strane zemalja predstavljenih kao najvećih trgovinskih partnera SAD-a, u razdoblju od 1982. do 2000. godine. Osim zakonske stope, ovo istraživanje je obuhvatilo efektivnu prosječnu stopu poreza na dobit i efektivnu graničnu stopu poreza na dobit kao pokazatelje djelovanja poreznih olakšica i poticaja, ali se statistički značajnom prikazala samo zakonska porezna stopa, čije povećanje doprinosi smanjenju izravnih stranih ulaganja.

Pavlović (2007) analizira utjecaj zakonske stope poreza na dobit na priljev izravnih stranih ulaganja u Hrvatskoj, u razdoblju od 1995. do 2005. godine, te dolazi do zaključka kako smanjenje zakonske stope poreza na dobit 2001. godine nije doprinijelo povećanju izravnih stranih ulaganja ${ }^{4}$. Isto tako, ističe kako smanjenje porezne stope i u ostalim zemljama u tranziciji i europskom području općenito, nije utjecalo bitno na donošenje investicijskih odluka.

Istraživanje Bezića i Pavlovića (2009) o utjecaju zakonske stope poreza na dobit za zemlje Srednje i Istočne Europe odnosno nove članice $\mathrm{EU}^{5}$ ne ukazuje na značajan utjecaj ove varijable na priljev izravnih stranih ulaganja. Naime, ova varijabla sama po sebi nije dovoljna za donošenje adekvatne lokacijske odluke, već je važnije makroekonomsko i društveno okruženje.

2 No, autorica vjeruje da ovakav stav i pod utjecajem osobnih motiva.

3 Navedeno je napredak ove varijable u odnosu na ranije globalno istraživanje u kojem je njen ran bio devet (MIGA, 202; prema Pavlović et al, 2011), što je u skladu s već iznesenim rezultatima ranijih istraživanja.

4 Razlog navedenoga može se, međutim, tražiti u ukidanju zaštitne kamate (opće olakšice u obliku neoporezivanja dobiti na razini zaštitne kamate).

5 Osim Cipra i Malte 
Prema panel analizi Bellaka i Leibrechta (2009), provedenoj u razdoblju od 1995. do 2003. godine na području Srednje i Istočne Europe, postoji negativna elastičnost izravnih stranih ulaganja u odnosu na efektivno porezno opterećenje poduzeća. Porezna politika, dakle, ima značajan utjecaj na odabir lokacije poslovanja kod investitora. Osim porezne politike, provedeno istraživanje naglašava ostale lokacijske prednosti države poput niskih troškova proizvodnje i veličine tržišta.

Olofsdotter i Hansson (2010) zaključuju da su nove članice Europske unije sklonije privlačenju izravnih stranih ulaganja snižavanjem stope poreza na dobit, što posebno dolazi do izražaja kada se promatraju izravna strana ulaganja u kapital povezanih društava, dok starije zemlje članice uspijevaju privući strani kapital bez obzira na primjenu viših poreznih stopa. Kao razlog navedenog posebno se ističe značaj pripadnosti ekonomskim integracijama. Analiza je provedena u razdoblju od 1995. do 2006. godine, a kao porezne varijable korištene su zakonska porezna stopa i efektivna granična porezna stopa.

Beck i Chaves (2011) u svom istraživanju uzimaju u obzir i dodatne porezne oblike, odnosno rad i potrošnju, u funkciji odljeva izravnih ulaganja. Istraživanje je provedeno na odabranim zemljama OECD-a, u razdoblju od 1975. do 2006. godine, a prikazuje kako povećanje stope poreza na dobit ima značajan i pozitivan utjecaj na odljev izravnih ulaganja, dok povećanje poreza na dohodak na rad negativno utječe na smanjenje odljeva stranih ulaganja. Porezi na potrošnju, koji se sagledavaju s pozicije dodatnog opterećenja rada, imaju nizak utjecaj na međunarodne investicijske tijekove.

Raudonen i Freytag (2013) provode analizu za područje Baltičkih zemalja u razdoblju od 2000. do 2008. godine, te zaključuju kako postoji značajan utjecaj zakonske i efektivne stope poreza na dobit na kretanje izravnih stranih ulaganja. Međutim, porezno opterećenje smatraju sekundarnim čimbenikom kojeg investitori uzimaju u obzir pri donošenju odluke o lokaciji poslovanja, dajući prednost veličini tržišta i stupnju ekonomske slobode.

Mateev i Tsekov (2014) provode panel analizu u razdoblju od 1994. do 2012. godine za 26 zemalja EU, dijeleći ih na EU 15 i nove članice (zemlje Srednje i Istočne Europe). I oni ističu značajan utjecaj tradicionalnih lokacijskih varijabli, među kojima i negativan utjecaj zakonske stope poreza na dobit u obje skupine zemalja.

\section{METODOLOGIJA ZNANSTVENOG ISTRAŽIVANJA}

Ekonometrijska analiza temelji se na provedbi statičke panel analize za razdoblje od 1998. do 2017. godine. Sastoji se od statičke panel analize koja se provodi na 28 zemalja članica Europske unije kao cjelini, analizi koja obuhvaća samo stare članice (EU 15) i analizi koja obuhvaća isključivo nove članice Europske unije, odnosno zemlje koje su pristupile članstvu od 2003. godine nadalje (EU 13).

Podaci su prikupljeni iz baze podataka Ujedinjenih naroda (UNCTADSTAT, 2018), Centra za europska ekonomska istraživanja (ZEW) (Spengel, 2018), Svjetske banke (World Bank, 2018.) i Eurostata (Eurostat, 2018).

U svrhu procjene ekonometrijskog modela koriste se slijedeće varijable: 
- FDI_STOCK:vrijednost izravnih stranih ulaganja kao udio u kapitalu i rezervama (uključujući zadržane dobitke) povezanog poduzeća, uvećan za neto vrijednost zaduživanja iz transakcija između povezanih društava; podaci se iskazuju u milijunima američkih dolara;

- CIT: najviša zakonska stopa poreza na dobit; podaci se iskazuju u postocima;

- EATR: efektivna prosječna stopa poreza na dobit; podaci se iskazuju u postocima;

- EMTR: efektivna granična stopa poreza na dobit; podaci se iskazuju u postocima;

- GDP: vrijednost bruto domaćeg proizvoda; podaci se iskazuju u milijunima američkih dolara;

- ULC: indeks vrijednosti jediničnog troška rada, kao odnos između troškova rada i efektivnih sati rada; podaci se iskazuju kao bazni indeks u odnosu na vrijednost iz 2010. godine;

- PDEBT: udio javnog duga u BDP-u; podaci se iskazuju u postotku;

- RD_EXP: udio državnih izdataka za istraživanje i razvoj u odnosu na ukupne proračunske izdatke; podaci se iskazuju u postotku;

- LOANS: udio domaćih kredita plasiranih u privatni sektor od strane financijskih institucija u odnosu na vrijednost BDP-a; Osim novčanih kredita, u navedenu kategoriju se ubraja i prodaja financijskih instrumenata koji nemaju obilježje kapitala te poslovi otkupa potraživanja; podaci se iskazuju u postotku;

- UNEMP: udio nezaposlene radne snage u odnosu na ukupno radno sposobno stanovništvo; podaci se iskazuju u postotku.

Izravna strana ulaganja u udjele kapitala povezanih društava, uvećane za neto vrijednost duga iz međusobnih transakcija (FDI_STOCK), predstavljaju zavisnu varijablu, dok su najviša zakonska stopa poreza na dobit (CIT), efektivna prosječna porezna stopa (EATR) i efektivna granična porezna stopa (EMTR) nezavisne varijable porezne politike.

Efektivna prosječna porezna stopa (Effective Average Tax Rate - EATR) i efektivna granična porezna stopa (Effective Marginal Tax Rate - EMTR) su mjere koje sintetiziraju zakonsku poreznu stopu, ali i ostale relevantne elemente poreza na dobit. Prvobitno su razvijene od strane Kinga i Fulertona (1984), da bi naknadno bile dorađene od strane Devereuxa i Griffitha (1999).

lako postoje različite varijante izračuna, $u$ ovom radu se koriste izračuni prema modelu efektivne prosječne porezne stope (EATR) i modelu efektivne granične porezne stope (EMTR) po metodologiji Devereuxa i Griffitha (1999) (Centre for European Economic Research 2018). S obzirom da se njihov izračun temelji na budućem kretanju projiciranih novčanih tokova od potencijalnih investicija nakon oporezivanja, diskontiranih po stopi koja odražava oportunitetni trošak investitora, smatraju se boljim izborom u svrhu donošenja odluka o investicijama (OECD, 2000:47). ${ }^{6}$

6 Prvi pojedinačni izračuni za samu Hrvatsku uslijedili su nakon nekoliko godina (Švaljek, 2006; Šimović, 2008). 
Porez na dobit te novčani tokovi projekta prije i nakon oporezivanja projiciraju se za cjelokupno predviđeni vijek efektuiranja investicije na način da se svode na sadašnju vrijednost kako bi investitori mogli realno procijeniti porezno opterećenje ulaganja. Pri tome se kao diskontna stopa uzima trošak kapitala kao ponderirana vrijednost kamatne stope na tuđe izvore financiranja i očekivani prinos investitora na uloženi vlastiti kapital.

U svrhu donošenja investicijskih odluka jednako su bitne obje efektivne stope, s time da je efektivna prosječna porezna stopa orijentirana na određivanje lokacije ulaganja, a efektivna granična porezna stopa na obujam ulaganja kapitala (Devereux et al., 2002:461).

Prema modelu Devereuxa i Griffitha efektivna se prosječna porezna stopa (EATR) računa na slijedeći način:

$$
\begin{aligned}
\text { EATR } & =\frac{R^{*}-R}{\frac{p}{(1+r)}} \\
R^{*} & =\frac{(p-r)}{(1+r)} \\
R & =\frac{(1+\delta)(1-\tau)-(r+\delta)(1-A)}{1+r}
\end{aligned}
$$

pri čemu je:

- $R^{*}$ neto sadašnja vrijednost investicije prije poreza

- $R$ neto sadašnja vrijednost investicije nakon poreza

- $p$ očekivana stopa povrata prije poreza

- $\delta$ stopa ekonomske amortizacije dugotrajne imovine

- $\tau$ stopa poreza na dobit

- $r$ diskontna stopa

- A neto sadašnja vrijednost amortizacijskih odbitaka

Iz navedenih jednadžbi moguće je definirati efektivnu prosječnu stopu poreza na dobit (EATR) kao odnos između razlike neto sadašnje vrijednosti investicije prije i nakon oporezivanja te sadašnje vrijednosti očekivane stope povrata prije oporezivanja.

Za razliku od efektivne prosječne porezne stope (EATR), koja prikazuje utjecaj kretanja poreza na dobit na trošak kapitala kao minimalne stope povrata na ulaganje, efektivna granična porezna stopa (EMTR) prikazuje utjecaj porezne politike na dodatnu novčanu jedinicu ulaganja, odnosno mjeri djelovanje poreznih poticaja na dodatno ulaganje.

Efektivna se granična stopa poreza na dobit (EMTR) računa na slijedeći način:

7 Osim isticanja zakonske stope poreza na dobit i ostalih elemenata poreza na dobit, određeni autori u izračun neto sadašnje vrijednosti investicije nakon poreza uključuju i ostale oblike direktnih poreza manjeg značaja, kao npr. porez na imovinu kod investiranja u određenu dugotrajnu imovinu (Spengel, 2018). Navedeno rezultira smanjenjem neto sadašnje vrijednosti investicije nakon poreza, odnosno većom efektivnom prosječnom poreznom stopom. 
$E M T R=\frac{(p i-r)}{p i}$

EMTR $=\frac{[c-(r+\delta)]}{c}=\left[\frac{(1-A)}{(1-\tau A)}\right] * \tau$

pri čemu je:

- $c$ trošak kapitala ${ }^{8}$

- pi trošak kapitala na graničnu investiciju

Iz navedenog slijedi kako je efektivna granična porezna stopa odnos razlike troška kapitala na dodatnu jedinicu investicije i diskontne stope i troška kapitala na dodatnu jedinicu ulaganja.

Investitori su spremni ulagati do trenutka u kojem je granična stopa povrata na ulaganje jednaka trošku kapitala. Stoga restriktivna fiskalna politika utječe na stvaranje visokog troška kapitala (Pirvu, 2012:86).

U slučaju kada efektivna granična porezna stopa poprima negativnu vrijednost $(E M T R<0)$, porezni sustav djeluje stimulirajuće na kapitalne investicije, s obzirom da u tom slučaju sadašnja vrijednost poreznih poticaja premašuje sadašnju vrijednost ulaganja. Ukoliko je efektivna granična porezna stopa jednaka nuli $(E M T R=0)$ porezni sustav je neutralan, a ukoliko je veća od nule porezni sustav ne djeluje poticajno. Što je veće odstupanje efektivne granične porezne stope u odnosu na nultu vrijednost, veći je utjecaj porezne politike na donošenje investicijskih odluka (OECD, 2000:49).

U kontrolne nezavisne varijable ubrajaju se:

- Bruto domaći proizvod (GDP), kao pokazatelj veličine tržišta i stupnja razvijenosti gospodarstva;

- Indeks jediničnog troška rada (ULC) kao pokazatelj efikasnosti rada;

- Udio javnog duga u BDP-u (PDEBT) kao pokazatelj rizičnosti;

- Udio državnih izdataka za istraživanje i razvoj u odnosu na ukupne proračunske izdatke (RD_EXP) kao pokazatelj odnosa države prema inovacijama;

- Udio domaćih kredita plasiranih u privatni sektor od strane financijskih institucija u BDP-u (LOANS) kao pokazatelj dostupnosti financijskih izvora;

- Udio nezaposlene radne snage u ukupno aktivnom stanovništvu (UNEMP) kao pokazatelji dostupnosti radne snage i stupnja razvijenosti gospodarstva.

Tablica 1 prikazuje očekivane predznake utjecaja nezavisnih varijabli unutar ekonometrijskih modela.

8 Kao u slučaju neto sadašnje vrijednosti investicije nakon poreza (pri izračunu efektivne prosječne porezne stope) i u okviru troška kapitala mogu biti uključeni i ostali direktni porezi (npr. porez na imovinu). Navedeno ima za posljedicu isticanje većeg troška kapitala, a time i veću efektivnu graničnu poreznu stopu. 
I. Banović, H. Blažić, S. Drezgić: Utjecaj poreza na dobit na kretanje izravnih stranih ulaganja u... Zbornik Veleučilišta u Rijeci, Vol. 8 (2020), No. 1, pp. 41-58

Tablica 1. Očekivani predznaci nezavisnih varijabli unutar ekonometrijskih modela

\begin{tabular}{|c|c|c|}
\hline VARIJABLA & $\begin{array}{l}\text { OČEKIVANI } \\
\text { PREDZNAK }\end{array}$ & OBJAŠNJENJE \\
\hline CIT & - & $\begin{array}{l}\text { Očekuje se da porast najviše zakonske porezne stope utječe na } \\
\text { smanjenje izravnih stranih ulaganja, s obzirom da investitorima } \\
\text { predstavlja veće novčane izdatke. }\end{array}$ \\
\hline EATR & - & $\begin{array}{c}\text { Očekuje se da porast efektivne prosječne porezne stope utječe na } \\
\text { smanjenje izravnih stranih ulaganja, s obzirom da investitorima } \\
\text { predstavlja veće novčane izdatke. }\end{array}$ \\
\hline EMTR & - & $\begin{array}{l}\text { Očekuje se da porast efektivne granične porezne stope utječe na } \\
\text { smanjenje izravnih stranih ulaganja, s obzirom da investitorima } \\
\text { predstavlja veće novčane izdatke. }\end{array}$ \\
\hline$G D P$ & + & $\begin{array}{c}\text { Očekuje se da porast bruto domaćeg proizvoda, kao pokazatelja } \\
\text { ekonomske aktivnosti i veličine tržišta, utječe na povećanje izravnih } \\
\text { stranih ulaganja. }\end{array}$ \\
\hline ULC & - & $\begin{array}{l}\text { Očekuje se da porast jediničnih troškova radne snage djeluje negativno } \\
\text { na izravna strana ulaganja, s obzirom da investitorima predstavlja veće } \\
\text { novčane izdatke. }\end{array}$ \\
\hline PDEBT & - & $\begin{array}{l}\text { Očekuje se da povećanje razine javnog duga utječe na smanjenje } \\
\text { izravnih stranih ulaganja, s obzirom da predstavlja povećanu izloženost } \\
\text { financijskom riziku zemlje. }\end{array}$ \\
\hline$R D \_E X P$ & + & $\begin{array}{l}\text { Očekuje se da povećanje državnih izdataka u istraživanje i razvoj } \\
\text { doprinosi povećanju izravnih stranih ulaganja, s obzirom da je riječ o } \\
\text { varijabli koja predstavlja stav države prema ekonomiji inovacija. }\end{array}$ \\
\hline LOANS & + & $\begin{array}{l}\text { Očekuje se da povećanje raspoloživih kredita u gospodarstvu utječe } \\
\text { na povećanje izravnih stranih ulaganja, budući da navedena varijabla } \\
\text { predstavlja pokazatelj dostupnosti financijskih izvora na tržištu novca } \\
\text { određene zemlje. }\end{array}$ \\
\hline UNEMP & + & $\begin{array}{l}\text { Očekuje se da povećanje stope nezaposlenosti utječe pozitivno } \\
\text { na povećanje izravnih stranih ulaganja, s obzirom da investitorima } \\
\text { predstavlja veću dostupnost radne snage na tržištu rada. }\end{array}$ \\
\hline
\end{tabular}

Izvor: izrada autora

Iz prikaza u tablici 1 može se uočiti kako eventualno povećanje varijabli poreznih stopa ima negativan utjecaj na kretanje izravnih stranih ulaganja, što je također prisutno i za varijablu indeksa jediničnog troška rada te udjela javnog duga u BDP-u.

Može se očekivati da rast bruto domaćeg proizvoda, udjela državnih izdataka u istraživanje i razvoj, dostupnosti kredita i nezaposlenosti a imaju pozitivan utjecaj na kretanje izravnih stranih ulaganja.

Ekonometrijska analiza temelji se na provedbi statičke panel analize, odnosno odabiru najprikladnijeg modela između združenog modela (Pooled regression model), modela s fiksnim efektom (Fixed effects model) i modela sa slučajnim efektom (Random effects model). 
Provedba F-testa upućuje na to da se model s fiksnim efektom smatra prikladnijim za provedbu u odnosu na združeni model, dok je prema Breusch-Pagan LM testu model sa slučajnim efektom prikladniji u odnosu na združeni model.

Kako bi se procijenilo je li za navedenu analizu prikladniji model s fiksnim efektom ili model sa slučajnim efektom, pomoću Hausmanovog testa procijenjeno je kako se model s fiksnim efektom može smatrati adekvatnim, a čiji je opći oblik:

$$
\begin{gathered}
Y_{i t}=\mu+\beta_{1} X_{i t 1}+\beta_{2} X_{i t 2}+\ldots+\beta_{K} X_{i t K}+\varepsilon_{i t} \\
i=1,2, \ldots \mathrm{N} ; t=1,2, \ldots \mathrm{T}
\end{gathered}
$$

Prilikom postavljanja ekonomskih ciljeva povezanih s investicijama, pretpostavlja se da je potreban određeni vremenski pomak kako bi sadašnje izmjene porezne politike postale efektivne, pa se u navedenim istraživanjima preporuča korištenje lagiranih nezavisnih varijabli (Mudenda, 2015:23). Iz navedenog slijedi analitički zapis jednadžbe ekonometrijske procjene:

$$
\begin{aligned}
& {\operatorname{lnFDI} S T O C K_{i t}}_{-}=\mu+\beta_{1} \ln X_{i, t-1}+\beta_{2} \ln G D P_{i, t-1}+\beta_{3} \ln U L C_{i, t-1}+ \\
& \beta_{4} \operatorname{lnPDEBT}_{i, t-1}+\beta_{5} \operatorname{lnRD}_{-} \operatorname{EXP}_{i, t-1}+\beta_{6} \operatorname{lnLOANS}_{i, t-1}+\beta_{7} \ln U N E M P_{i, t-1}+\varepsilon_{i t}
\end{aligned}
$$

pri čemu je:

- InFDI_STOCK ${ }_{\text {it }}$ logaritmirana vrijednost izravnih stranih ulaganja u udjele povezanih društava, uvećanih za vrijednost neto duga iz međusobnih transakcija, zemlje i u razdoblju $t$

- $\quad \ln _{\mathrm{xi},-1}$ logaritmirana vrijednost varijable porezne stope, pri čemu je:

- InCIT ${ }_{i, t-1}$ najviša zakonska stopa poreza na dobit zemlje i u razdoblju

$\mathrm{t}-1$, u prvom modelu

- InEATR ${ }_{i, t-1}$ efektivna prosječna stopa poreza na dobit zemlje i u razdoblju $t-1, \mathrm{u}$ drugom modelu

- InEMTR $R_{i, t-1}$ efektivna granična stopa poreza na dobit zemlje i u razdoblju t-1, u trećem modelu;

- $\quad \operatorname{lnGDP}_{\mathrm{i}, \mathrm{t}-1}$ logaritmirana vrijednost bruto domaćeg proizvoda zemlje i u razdoblju t-1;

- $\quad \ln U L C_{\mathrm{i},-1}$ logaritmirana vrijednost indeksa jediničnog troška rada zemlje i u razdoblju t-1;

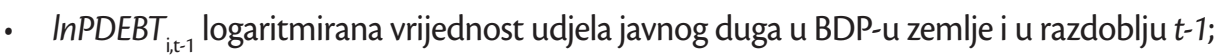

- InRD_EXP $P_{i,-1}$ logaritmirana vrijednost udjela izdataka za istraživanje i razvoj u ukupnim proračunskim izdacima zemlje i u razdoblju $t$-1;

- InLOANS ${ }_{i,-1-1}$ logaritmirana vrijednost udjela domaćih kredita, plasiranih privatnom sektoru od strane financijskih institucija, u BDP-u zemlje i u razdoblju t-1; 
- InUNEMP ${ }_{\mathrm{i}, \mathrm{t}-\mathrm{l}}$ logaritmirana vrijednost udjela nezaposlenih osoba u ukupno radno aktivnom stanovništvu zemlje i u razdoblju t-1;

- $\mu$ konstantni član;

- $\quad$ it greška relacije zemlje i u razdoblju t;

- $b_{1} b_{2} b_{3} b_{4} b_{5} b_{6} b_{7}$ parametri koje je potrebno procijeniti.

\section{EMPIRIJSKA ANALIZA I REZULTATI ISTRAŽIVANJA}

Panel analiza provedena je putem tri različite skupine modela. Rezultati su strukturirani na način da obuhvaćaju analizu cijele Europske unije (EU28), analizu koja se temelji isključivo na starim zemljama članicama Europske unije (EU15) i analizu koja obuhvaća isključivo nove članice Europske unije (EU13).

Tablica 2 prikazuje rezultate provedene ekonometrijske analize na području Europske unije kao cjeline (EU28).

Tablica 2. Rezultati provedene ekonometrijske panel analize u zemljama članicama Europske unije (EU 28)

\begin{tabular}{|c|c|c|c|}
\hline VARIJABLA & MODEL 1 & MODEL 2 & MODEL 3 \\
\hline $\operatorname{lnClT} T_{i, t-1}$ & $\begin{array}{l}-0.183^{* *} \\
(0.0897)\end{array}$ & - & - \\
\hline $\ln E A T R_{\mathrm{i}, t-1}$ & - & $\begin{array}{c}-0.380^{* * *} \\
(0.0911)\end{array}$ & - \\
\hline $\operatorname{InEMTR}_{\mathrm{i}, \mathrm{t}-1}$ & - & - & $\begin{array}{c}-0.221^{* * *} \\
(0.0520)\end{array}$ \\
\hline $\ln G D P_{\mathrm{i}, \mathrm{t}-1}$ & $\begin{array}{l}0.830^{* * *} \\
(0.0671)\end{array}$ & $\begin{array}{l}0.911^{* * *} \\
(0.0650)\end{array}$ & $\begin{array}{l}0.767^{* * *} \\
(0.0618)\end{array}$ \\
\hline $\ln U L C_{i, t-1}$ & $\begin{array}{l}0.0878 \\
(0.136) \\
\end{array}$ & $\begin{array}{l}0.0282 \\
(0.134) \\
\end{array}$ & $\begin{array}{c}0.256 \\
(0.165)\end{array}$ \\
\hline $\operatorname{InPDEBT_{\mathrm {i},\mathrm {t}-1}}$ & $\begin{array}{c}0.107 \\
(0.0655)\end{array}$ & $\begin{array}{c}0.113^{*} \\
(0.0643)\end{array}$ & $\begin{array}{c}0.119 * \\
(0.0638)\end{array}$ \\
\hline $\ln R D \_E X P_{i, t-1}$ & $\begin{array}{c}0.109 \\
(0.0853)\end{array}$ & $\begin{array}{c}0.0980 \\
(0.0839)\end{array}$ & $\begin{array}{c}0.122 \\
(0.0835)\end{array}$ \\
\hline $\operatorname{InLOANS}{ }_{\mathrm{i},-1-1}$ & $\begin{array}{c}0.107 \\
(0.0910)\end{array}$ & $\begin{array}{c}0.0662 \\
(0.0888)\end{array}$ & $\begin{array}{c}0.0812 \\
(0.0879)\end{array}$ \\
\hline $\ln U N E M P_{i, t-1}$ & $\begin{array}{c}0.0530 \\
(0.0599)\end{array}$ & $\begin{array}{c}0.0779 \\
(0.0591)\end{array}$ & $\begin{array}{c}0.0264 \\
(0.0581)\end{array}$ \\
\hline Konstanta & $\begin{array}{c}0.746^{* * *} \\
(0.145)\end{array}$ & $\begin{array}{c}0.704^{* * *} \\
(0.143)\end{array}$ & $\begin{array}{c}0.878^{* * *} \\
(0.152)\end{array}$ \\
\hline $\mathrm{N}$ & 393 & 393 & 388 \\
\hline
\end{tabular}

Napomena: u zagradama su prikazane standardne greške;

* statistička signifikantnost na razini od $10 \%$, ** statistička signifikantnost na razini od $5 \%$,

*** statistička signifikantnost na razini od $1 \%$ 
Na temelju provedene panel analize u Europskoj uniji kao cjelini (EU28), može se primijetiti kako su statistički značajne varijable koje predstavljaju poreznu politiku, bruto domaći proizvod i udio javnog duga u BDP-u.

Prvi model je predstavljen nezavisnom varijablom najviše zakonske porezne stope ( $\left.\operatorname{lnCIT} T_{\mathrm{i}, \mathrm{t}-1}\right)$, koja je statistički signifikantna na razini od $5 \%$, a iz njene vrijednosti je moguće zaključiti kako postotno povećanje zakonske porezne stope utječe na smanjenje razine izravnih stranih ulaganja u kapital povezanih društava (InFDI_STOCK) za 0,18 \%.

Drugi model je predstavljen nezavisnom varijablom efektivne prosječne stope poreza na dobit $\left(\operatorname{InEATR} R_{\mathrm{i}, \mathrm{t}-1}\right)$, koja je statistički signifikantna na razini od $1 \%$, a prikazuje kako postotno povećanje njene vrijednosti utječe na smanjenje izravnih stranih ulaganja u kapital povezanih društava (InFDI_STOCK) za 0,38 \%. Iz navedenog proizlazi kako je riječ o poreznoj varijabli koja ima najznačajniji utjecaj na kretanje zavisne varijable (InFDI_STOCK) u promatranim modelima.

Treći model je predstavljen nezavisnom varijablom efektivne granične stope poreza na dobit $\left(\operatorname{lnEMTR}{ }_{\mathrm{i}, \mathrm{t}-1}\right)$, koja također poprima statističku značajnost na razini od $1 \%$, a prikazuje kako postotno povećanje njene vrijednosti uzrokuje smanjenje izravnih stranih ulaganja u kapital povezanih društava (InFDI_STOCK) za 0,22 \%.

Analizom pomoćnih nezavisnih varijabli moguće je primijetiti kako u sva tri modela prevladava značajnost bruto domaćeg proizvoda $\left(\operatorname{lnGDP_{i,t-1}}\right)$. Riječ je o nezavisnoj varijabli koja ima najveći utjecaj na kretanje zavisne varijable u analiziranoj strukturi, odnosno promatranjem vrijednosti u sva tri modela, može se primijetiti kako postotno povećanje bruto domaćeg proizvoda utječe na povećanje izravnih stranih ulaganja u kapital povezanih društava (InFDI_STOCK) u rasponu od 0,77\% do 0,91\%.

Od ostalih nezavisnih varijabli, statistički značajna se prikazuje samo varijabla udjela javnog duga u BDP-u (InPDEBT $T_{i,-1}$ ), ali samo u okviru drugog i trećeg modela, na razini signifikantnosti od $10 \%$. S obzirom da navedena varijabla ne poprima pozitivni predznak, proizlazi kako povećanje javnog duga u analizi Europske unije kao cjeline ne djeluje destimulirajuće na investitore pri donošenju odluke o ulaganju.

Tablica 3 prikazuje rezultate provedene ekonometrijske panel analize na području starih članica Europske unije (EU15). 
I. Banović, H. Blažić, S. Drezgić: Utjecaj poreza na dobit na kretanje izravnih stranih ulaganja u... Zbornik Veleučilišta u Rijeci, Vol. 8 (2020), No. 1, pp. 41-58

Tablica 3. Rezultati provedene ekonometrijske panel analize u starim zemljama članicama Europske unije (EU 15)

\begin{tabular}{|c|c|c|c|}
\hline VARIJABLA & MODEL 1 & MODEL 2 & MODEL 3 \\
\hline $\operatorname{lnClT} T_{i, t-1}$ & $\begin{array}{c}0.140 \\
(0.116)\end{array}$ & - & - \\
\hline $\operatorname{lnEATR}_{\mathrm{i}, \mathrm{t}-1}$ & 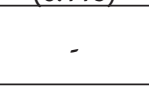 & $\begin{array}{l}-0.140 \\
(0.118)\end{array}$ & - \\
\hline $\ln E M T R_{\mathrm{i}, \mathrm{t}-1}$ & - & - & $\begin{array}{l}-0.107^{* *} \\
(0.0493)\end{array}$ \\
\hline $\operatorname{lnGDP_{i,t-1}}$ & $\begin{array}{l}0.611^{* * *} \\
(0.0779)\end{array}$ & $\begin{array}{l}0.711^{* * *} \\
(0.0778)\end{array}$ & $\begin{array}{l}0.679^{* * *} \\
(0.0657)\end{array}$ \\
\hline $\ln U L C_{i, t-1}$ & $\begin{array}{l}0.396^{*} \\
(0.227)\end{array}$ & $\begin{array}{l}0.401^{*} \\
(0.227)\end{array}$ & $\begin{array}{l}0.442^{* *} \\
(0.222)\end{array}$ \\
\hline $\ln P D E B T_{i, t-1}$ & $\begin{array}{l}0.482^{* * *} \\
(0.0865)\end{array}$ & $\begin{array}{l}0.446^{* * *} \\
(0.0862)\end{array}$ & $\begin{array}{l}0.465^{* * *} \\
(0.0818)\end{array}$ \\
\hline $\ln R D \_E X P_{i, t-1}$ & $\begin{array}{l}-0.0532 \\
(0.102)\end{array}$ & $\begin{array}{l}-0.0531 \\
(0.101) \\
\end{array}$ & $\begin{array}{c}-0.0720 \\
(0.0979)\end{array}$ \\
\hline $\ln L O A N S_{i, t-1}$ & $\begin{array}{c}-0.144 \\
(0.117)\end{array}$ & $\begin{array}{l}-0.165 \\
(0.116) \\
\end{array}$ & $\begin{array}{c}-0.173 \\
(0.113) \\
\end{array}$ \\
\hline $\ln U N E M P_{i, t-1}$ & $\begin{array}{l}-0.170^{* *} \\
(0.0756)\end{array}$ & $\begin{array}{c}-0.150^{*} \\
(0.0762)\end{array}$ & $\begin{array}{l}-0.170^{* *} \\
(0.0727)\end{array}$ \\
\hline Konstanta & $\begin{array}{l}1.189^{* * *} \\
(0.182)\end{array}$ & $\begin{array}{c}0.958^{* * *} \\
(0.181)\end{array}$ & $\begin{array}{l}1.042^{* * *} \\
(0.161) \\
\end{array}$ \\
\hline $\mathrm{N}$ & 233 & 233 & 228 \\
\hline
\end{tabular}

Napomena: u zagradama su prikazane standardne greške;

* statistička signifikantnost na razini od $10 \%$,** statistička signifikantnost na razini od $5 \%$,

*** statistička signifikantnost na razini od $1 \%$.

Izvor: Izračun autora

Temeljem prikaza izračunatih koeficijenata u tablici 2 može se primijetiti kako u prvom i drugom modelu varijable porezne politike nisu značajne, dok se u trećem modelu varijabla efektivne granične porezne stope $\left(\ln E M T R_{i, t-1}\right)$ prikazuje statistički signifikantnom na razini od $5 \%$. Promatranjem koeficijenta navedene varijable, moguće je primijetiti kako njeno postotno povećanje utječe na smanjenje izravnih stranih ulaganja u kapital povezanih društava (InFDI_STOCK) za 0,11 \%.

Od ostalih nezavisnih pomoćnih varijabli kod starih zemalja članica, do izražaja dolazi razina bruto domaćeg proizvoda $\left(\operatorname{InGDP}_{i, t-1}\right)$, koja je statistički signifikantna na razini od $1 \%$, a njeno postotno povećanje utječe na rast zavisne varijable (InFDI_STOCK) u rasponu od 0,61 \% do 0,71\%, ovisno o promatranom modelu.

Varijabla indeksa jediničnog troška rada $\left(\operatorname{InULC_{i,t-1}}\right)$ značajna je na razini signifikantnosti od $10 \% \mathrm{u}$ prvom i drugom modelu, dok u trećem modelu poprima vrijednost od $5 \%$. Njen predznak je pozitivan, što upućuje na to da njeno povećanje na području starih zemalja članica (EU15) ne djeluje destimulirajuće na povećanje izravnih stranih ulaganja, odnosno postotno povećanje navedene varijable utječe na rast izravnih stranih ulaganja u kapital povezanih društava (InFDI_STOCK) u rasponu od $0,40 \%$ do $0,44 \%$, ovisno o promatranom modelu. 
Povećanje varijable javnog duga ( InPDEBT ${ }_{\mathrm{i}, \mathrm{-}-1}$ ) statistički je značajno na razini od $1 \%$ u svim prikazanim modelima, a upućuje na to kako njeno postotno povećanje uzrokuje rast izravnih stranih ulaganja u kapital povezanih društava (InFDI_STOCK) u rasponu od 0,45 \% do 0,48 \%, ovisno promatranom modelu. Navedeno kretanje također upućuje na to da rast javnog duga djeluje stimulirajuće na povećanje izravnih stranih ulaganja u starim zemljama članicama Europske unije.

Varijabla koja predstavlja udio nezaposlenih u aktivnom stanovništvu (InUNEMP $\left.{ }_{i, t-1}\right)$ statistički je značajna na razini od $5 \%$ u prvom i trećem modelu, dok je u drugom modelu značajna na razini od $10 \%$. Njeno postotno povećanje djeluje destimulirajuće na kretanje izravnih stranih ulaganja u kapital povezanih društava (InFDI_STOCK) u rasponu od 0,15 \% do 0,17\% u ovisnosti o promatranom modelu.

Tablica 4 prikazuje rezultate provedene ekonometrijske panel analize na području novih članica Europske unije.

Tablica 4. Rezultati provedene ekonometrijske panel analize u novim zemljama članicama Europske unije (EU13)

\begin{tabular}{|c|c|c|c|}
\hline VARIJABLA & MODEL 1 & MODEL 2 & MODEL 3 \\
\hline $\operatorname{lnCl} T_{\mathrm{i}, \mathrm{t}-1}$ & $\begin{array}{c}-0.245 \\
(0.153)\end{array}$ & - & - \\
\hline $\operatorname{InEATR} R_{\mathrm{i}, \mathrm{t}-1}$ & - & $\begin{array}{c}-0.355^{* *} \\
(0.156)\end{array}$ & - \\
\hline $\operatorname{InEMTR} R_{\mathrm{i},-1-1}$ & - & - & $\begin{array}{c}-0.301^{* *} \\
(0.113)\end{array}$ \\
\hline $\operatorname{lnGDP} P_{\mathrm{i},-1-1}$ & $\begin{array}{c}0.830^{* * * *} \\
(0.136)\end{array}$ & $\begin{array}{c}0.880^{* * * *} \\
(0.134)\end{array}$ & $\begin{array}{c}0.855^{* * *} \\
(0.121)\end{array}$ \\
\hline $\ln U L C_{\mathrm{i},-1}$ & $\begin{array}{l}-0.0288 \\
(0.213) \\
\end{array}$ & $\begin{array}{l}-0.0751 \\
(0.210) \\
\end{array}$ & $\begin{array}{c}-0.00641 \\
(0.196)\end{array}$ \\
\hline $\ln P D E B T_{\mathrm{i}, \mathrm{t}-1}$ & $\begin{array}{l}-0.0876 \\
(0.109) \\
\end{array}$ & $\begin{array}{r}-0.0703 \\
(0.108) \\
\end{array}$ & $\begin{array}{l}-0.0774 \\
(0.107)\end{array}$ \\
\hline $\ln R D_{-} \in X P_{\mathrm{i}, \mathrm{t}-1}$ & $\begin{array}{l}0.259^{*} \\
(0.139)\end{array}$ & $\begin{array}{l}0.252^{*} \\
(0.138)\end{array}$ & $\begin{array}{l}0.292^{* *} \\
(0.137)\end{array}$ \\
\hline $\ln L O A N S_{i, t-1}$ & $\begin{array}{c}0.240 \\
(0.146)\end{array}$ & $\begin{array}{c}0.213 \\
(0.144) \\
\end{array}$ & $\begin{array}{c}0.162 \\
(0.148) \\
\end{array}$ \\
\hline $\ln U N E M P_{i, t-1}$ & $\begin{array}{l}0.287^{* *} \\
(0.104)\end{array}$ & $\begin{array}{l}0.284^{* *} \\
(0.104)\end{array}$ & $\begin{array}{l}0.230^{* *} \\
(0.0971)\end{array}$ \\
\hline Konstanta & $\begin{array}{l}1.299^{* * *} \\
(0.292)\end{array}$ & $\begin{array}{l}1.289^{* * *} \\
(0.294)\end{array}$ & $\begin{array}{l}1.332^{* * *} \\
(0.295)\end{array}$ \\
\hline $\mathrm{N}$ & 159 & 159 & 159 \\
\hline
\end{tabular}

Napomena: u zagradama su prikazane standardne greške;

* statistička signifikantnost na razini od $10 \%$, ${ }^{* *}$ statistička signifikantnost na razini od $5 \%$,

*** statistička signifikantnost na razini od $1 \%$

Izvor: Izračun autora 
$\mathrm{Na}$ temelju prikazanih koeficijenata u tablici 4 može se uočiti kako u novim zemljama članicama Europske unije efektivne porezne stope imaju značajniji utjecaj na kretanje izravnih stranih ulaganja u kapital povezanih društava (InFDI_STOCK).

U prvom se modelu može uočiti kako je utjecaj najviše zakonske porezne stope ( $\left.\ln C I T_{i, t-1}\right)$ na zavisnu varijablu (InFDI_STOCK) negativan, ali i kako nezavisna varijabla sama po sebi ne zadovoljava uvjet statističke značajnosti.

Varijabla efektivne prosječne porezne stope $\left(\operatorname{InEATR}_{\mathrm{i}, \mathrm{t}-1}\right)$ statistički je značajna na razini signifikantnosti od $5 \%$ te prikazuje kako njeno postotno povećanje utječe na smanjenje izravnih stranih ulaganja u kapital povezanih društava (InFDI_STOCK) za 0,36 \%. Iz navedenog se uočava ista pojava kao i u slučaju analize koja promatra Europsku uniju kao cjelinu, odnosno da je riječ o poreznoj varijabli koja i kod novih zemalja članica ima najznačajniji utjecaj na kretanje zavisne varijable.

$U$ trećem je modelu varijabla efektivne granične porezne stope $\left(\operatorname{InEMTR}_{\mathrm{i},-1-1}\right)$ također statistički značajna na razini od $5 \%$ signifikantnosti, a njeno postotno povećanje utjecat će na smanjenje izravnih stranih ulaganja u kapital povezanih društava (InFDI_STOCK) za $0,30 \%$.

Promatranjem ostalih, pomoćnih nezavisnih varijabli, može se uočiti kako utjecaj bruto domaćeg proizvoda $\left(\operatorname{InGDP} P_{i,-t-1}\right)$ također pozitivno utječe na rast izravnih stranih ulaganja u kapital povezanih društava (InFDI_STOCK), kao i kod analize starih zemalja članica, odnosno njegovo postotno povećanje doprinosi rastu zavisne varijable u rasponu od 0,83 $\%$ do $0,86 \%$. Riječ je o varijabli koja ima najveći utjecaj na kretanje izravnih stranih ulaganja u kapital povezanih društava (InFDI_STOCK), a njena statistička signifikantnost je na razini od $5 \%{ }^{9}$

Udio državnih izdataka za istraživanje i razvoj $\left(\operatorname{InRD} \_E X P_{i, t-1}\right)$ statistički je značajna varijabla na razini od $10 \%$ u prvom i drugom modelu te na razini od $5 \%$ u trećem modelu. Njeno povećanje utječe pozitivno na zavisnu varijablu u novim zemljama članicama, odnosno postotno povećanje udjela državnih izdataka za istraživanje i razvoj ( InRD_EXP $\left.{ }_{i, t-1}\right)$ uzrokuje rast kretanje izravnih stranih ulaganja u kapital povezanih društava (InFDI_STOCK) u rasponu od $0,25 \%$ do $0,29 \%$, ovisno o promatranom modelu.

Varijabla udjela nezaposlenosti u radno aktivnom stanovništvu (InUNEMP $\left.{ }_{i, t,-1}\right)$ značajna je za sva tri promatrana modela na razini signifikantnosti od $5 \%$, a njeno postotno povećanje utjecat će pozitivno na kretanje zavisne varijable (InFDI_STOCK), odnosno povećat će se u rasponu od $0,23 \%$ do $0,29 \%$ ovisno o promatranom modelu.

9 Daljnja analiza utjecaja same porezne i općenito fiskalne politike na BDP, posebice novih zemalja članica EU odnosno bivših socijalističkih zemalja, je izvan dometa ovoga rada, no ukazujemo na različitost rezultata najrecentnijih istraživanja koja dovode i u pitanje neke tradicionalne postavke (npr. Grdinić et al., 2017; Deskar-Škrbić, 2018; Došenović Bonča, Tajnikar, 2018; Donath, Mura, 2019; Ko, 2019 ). 


\section{ZAKLJUČAK}

U svrhu povećanja priljeva izravnih stranih ulaganja, države su potencijalnim investitorima spremne ponuditi privlačne porezne uvjete; posebice u okviru poreza na dobit. Osim niže zakonske stope/stopa, uključuju se razne porezne olakšice i poticaji, što među državama utječe na stvaranje porezne konkurencije, a na strani multinacionalnih kompanija razvojem složenih tehnika poreznog planiranja. Kretanje zakonske porezne stope i efektivnih stopa poreza na dobit, u posljednja dva desetljeća u zemljama Europske unije ukazuje na smanjenje poreznog opterećenja i jačanje porezne konkurencije, posebice u novim zemljama članicama u odnosu na stare zemlje članice.

Panel analiza na razini Europske unije ukazuje kako porezna politika utječe na privlačenje izravnih stranih ulaganja, ali kao sekundarni čimbenik, ističući pri tom prednost varijable bruto domaćeg proizvoda.

Među analiziranim poreznim varijablama, efektivna prosječna porezna stopa se ističe kao najznačajnija u donošenju investicijskih odluka pri odabiru lokacije ulaganja.

Usporedna analiza između starih i novih zemalja članica prikazuje kako značajnost efektivnih poreznih stopa dolazi do izražaja u novim zemljama članicama, što potvrđuje aktivno korištenje porezne politike u svrhu privlačenja izravnih stranih ulaganja.

Ovim radom nije obuhvaćen utjecaj oporezivanja dobiti na odljev stranih ulaganja u analiziranim zemljama, kao ni djelovanje efektivnih poreznih stopa na prekogranične investicije u Hrvatskoj od strane zemalja iz kojih pritječe većina stranih investicija, što predstavlja preporuku za buduća znanstvena istraživanja. Isto tako, buduća bi se istraživanja mogla proširiti u smjeru izravnog obuhvata i drugih različitih poreznih i neporeznih opterećenja.

*Ovaj rad je financiran sredstvima Sveučilišta u Rijeci za projekt ZP UNIRI 3/19

\section{LITERATURA}

Bellak, C., Leibrechta, M. (2009) "Do low corporate income tax rates attract FDI? - Evidence from Central- and East European countries", Applied Economics, 41 (21), str. 2691-2703. https://doi.org/10.1080/00036840701320217

Beck, S., Chaves, A. (2011) The impact of various taxes on foreign direct investment, Newark: University of Delaware, Department of Economics

Bezić, H., Pavlović, D. (2009) “Corporate Tax Rate and Inflow of FDI“, In: Kandžija, V., Kumar, A. (ed.)., 50 Years of European Union, Rijeka: University of Rijeka, Facultiy of Economics

Billington, N. (1999) “The location of foreign direct investment: an empirical analysis", Applied Economics, 31:1, pp. 65-76. https://doi.org/10.1080/00036846.2019.12067087

Boskin, M. J., Gale, W. G. (1987) "New Results on the Effects of Tax Policy on the International Location of Investment", In: Feldstein, M. (ed.), The Effects of Taxation on Capital Accumulation, Chicago: UCP.

Carstensen, K., Toubal, F., 2004. "Foreign direct investment in Central and Eastern European countries: a dynamic panel analysis". Journal of Comparative Economics, 32(1), pp. 3-22. https://doi.org/10.1016/j.jce.2003.11.001 
I. Banović, H. Blažić, S. Drezgić: Utjecaj poreza na dobit na kretanje izravnih stranih ulaganja u...

Zbornik Veleučilišta u Rijeci, Vol. 8 (2020), No. 1, pp. 41-58

Deskar-škrbić, M. (2018) "Dynamic effects of fiscal policy in Croatia: confronting New-Keynesian SOE theory with empirics" Zbornik radova Ekonomskog fakulteta u Rijeci: časopis za ekonomsku teoriju i praksu/Proceedings of Rijeka Faculty of Economics: Journal of Economics and Business, 36 (1), pp. 83-102. https://doi.org/10.18045/zbefri.2018.1.83

Devereux, M., Griffith, R. (1999) The Taxation of Discrete Investment Choices, IFS Working Paper Series, No. W98/16. https://doi.org/10.1920/wp.ifs.1998.9816

Devereux, M. P., Griffith, R., Klemm, A. (2002) "Corporate Income Tax Reforms and International Tax Competition", Economic Policy, 17 (35), pp. 449-495. https://doi.org/10.1111/1468-0327.00094

Donath, L. E. and Mura, P.O. (2019) „The Looming Central and Eastern European Real Convergence Club: Do Implicit Tax Rates Play a Part?" Danube: Law and Economics Review, 10 (1), pp. 67-89. https://doi.org/10.2478/danb-20190004

Došenović Bonča, P. and Tajnikar M. (2018) "Austerity policies, economic growth and fiscal balance: lessons from Slovenia", Zbornik radova Ekonomskog fakulteta u Rijeci: časopis za ekonomsku teoriju i praksu/Proceedings of Rijeka Faculty of Economics: Journal of Economics and Business, 36 (1), pp. 287-308. https://doi.org/10.18045/zbefri.2018.1.287

Eurostat (2019) Total GBAORD as a \% of total general government expenditure, http://appsso.eurostat.ec.europa.eu/ nui/show.do?dataset=gba_nabste\&lang=en (10.01.2019.)

Eurostat (2019) Labour productivity and unit labour costs, http://appsso.eurostat.ec.europa.eu/nui/ submitViewTableAction.do (10.01.2019.)

Eurostat (2019) Government deficit/surplus, debt and associated data, http://appsso.eurostat.ec.europa.eu/nui/ submitViewTableAction.do (10.01.2019.)

Gorter, J., Parikh, A. (2003) "How Sensitive Is FDI to Differences in Corporate Income Taxation within the EU?", De Economist 151 (2), pp. 193-204. https://doi.org/10.1023/A:1023913618978

Grdinić, M., Drezgić, S., Blažić, H. (2017) „An Empirical Analysis of the Relationship between Tax Structures and Economic Growth in CEE Countries", Ekonomicky Casopis/Journal of Economics 65 (5), pp. $426-447$.

Hartman, D. G. (1984) "Tax Policy and Foreign Direct Investment in the United States", National Tax Journal, 37 (4), pp. 475-487. https://doi.org/10.3386/w0967

Jovančević, R. (2003) „FDls in Croatia: Implication of the Liberalised Policy From Manager's Perspective“, Naše gospodarstvo Revija za aktualna gospodarska vprašanja, 49 (5-6), pp. 465-480.

Kate, F., Milionis, P. (2019) „Is capital taxation always harmful for economic growth?” International Tax and Public Finance, 26(4), pp. 758 - 805. https://doi.org/10.1007/s10797-019-09530-3

King, M. A., Fullerton, D. (1984) The Taxation of Income from Capital: A Comparative Study of the U.S., U.K., Sweden, and West Germany-The Theoretical Framework, NBER Working Paper, No. 1058.

Ko, M.-C. (2019) "Fiscal Policy, Government Debt, and Economic Growth in the Kaleckian Model of Growth and Distribution“, Journal of Post Keynesian Economics, 42 (2), pp. 215-231. https://doi.org/10.1080/01603477.201 8.1503056

Kostial, K., Gropp, R., (2000) The disappearing tax base: is foreign direct investment eroding corporate income taxes?, Frankfurt am Main: European Central Bank

Mateev, M., Tsekov, I. (2014) "Are there any top FDI performers among EU-15 and CEE countries? A comparative panel data analysis", Financial theory and practice, 38 (3), pp. 337-374. https://doi.org/10.3326/fintp.38.3.4

de Mooij, R. A., Ederveen, S. (2003) "Taxation and Foreign Direct Investment: A Synthesis of Empirical Research", International Tax and Public Finance, 10 (6), pp. 673-693. https://doi.org/10.1023/A:1026329920854

Morisset, J. (2003) “Tax Incentives: Using Tax Incentives to Attract Foreign Direct Investment", Viewpoint: Public Policy for the Private Sector, February 2003, Note No. 253. World Bank, pp. 1-4. https://openknowledge.worldbank.org/ bitstream/handle/10986/11325/255210NEWSOREP10Box345634B01PUBLIC1.pdf (16.07.2019.)

Mudenda, L. (2015) Corporate Income Tax Rate and Foreign Direct Investment, Umea: Umea University 
OECD (2000) Tax Burdens - Alternative Measures, OECD Tax Policy Studies, No. 2, Paris: OECD Publishing

OECD (2001) Corporate Tax Incentives for Foreign Direct Investment. OECD Tax Policy Studies, No.4. Paris: OECD Publishing

OECD (2003) Tax Policy Assessment and Design in Support of Direct Investment: A Study of Countries in South East Europe, Paris: OECD Publishing

Olofsdotter, K., Hansson, A. (2010) Tax Differences and Foreign Direct Investment in the EU27, Lund: Department of Economics, Lund University

Pavlovic, D. (2007) “Utjecaj visine poreza na dobit na priljev inozemnih stranih ulaganja", Ekonomski pregled, 58 (11), pp. $732-748$.

Pavlović, D., Ćosić, D., Stojsavljević, S. (2011) “Razlike u vrednovanju inozemne lokacije za izravna ulaganja“, Ekonomski vjesnik : časopis Ekonomskog fakulteta u Osijeku, 1 (2011), pp. 61-71

Pirvu, D. (2012) Corporate Income Tax Harmonization in the European Union, London: Palgrave Macmillan

Raudonen, S., Freytag, A. (2013) "Determinants of FDI inflows into the Baltic Countries: Empirical Evidence from a Gravity Model",Journal of Business and Economics, 4 (2), pp. 180-194

Spengel, C. et al. (2018) Effective Tax Levels Using the Devereux/Griffith Methodology - Update 2017, Project for the EU Commission TAXUD/2013/CC/120 Final Report 2017, Mannheim: ZEW, https://ec.europa.eu/taxation_customs/ sites/taxation/files/final_report_2017_effective_tax_levels_revised_en.pdf (07. 10. 2018.)

Šimović, H, (2009) "Effective Corporate Income Tax Burden in Croatia", International Review of Economics \& Business, 12(2) pp. 107-121.

Švaljek, S. (ed.) (2006) Efektivno porezno opterećenje trgovačkih društava u Republici Hrvatskoj, Zagreb: Ekonomski institut

UNCTADSTAT (2019) Foreign direct investment: Inward and outward flows and stock, http://unctadstat.unctad.org/ wds/TableViewer/tableView.aspx?Reportld=96740 (10.01.2019.)

UNCTADSTAT (2019) Gross domestic product, https://unctadstat.unctad.org/wds/TableViewer/tableView. aspx?Reportld=96 (10.01.2019.)

Wijeweera, A., Dollery, B. and Clark, D. (2007) "Corporate tax rates and foreign direct investment in the United States", Applied Economics, 39(1), pp. 109-117. https://doi.org/10.1080/00036840500447872

World Bank (2019) Domestic credit to private sector by banks (\% of GDP), https://data.worldbank.org/indicator/ FD.AST.PRVT.GD.ZS (10. 01.2019.)

World Bank (2019) Unemployment, total (\% of total labor force), https://data.worldbank.org/indicator/SL.UEM.TOTL. ZS (10.01.2019.) 


\title{
THE IMPACT OF THE CORPORATE INCOME TAX ON THE FDI FLOWS IN THE EU MEMBER COUNTRIES
}

\author{
Igor Banović \\ Specialist in Finance (MBA), Audit Assistant, Medicom d. o. o., Meštrovićeva 16, 51000 Rijeka, Croatia; \\ e-mail: igor.banovic@hotmail.com
}

\section{Helena Blažić}

PhD, Full Professor - Tenured Professor, University of Rijeka, Faculty of Economics and Business, Ivana Filipovića 4, 51000 Rijeka, Croatia; e-mail: helena.blazic@efri.hr

\section{Saša Drezgić}

$\mathrm{PhD}$, Associate Professor, University of Rijeka, Faculty of Economics and Business, Ivana Filipovića 4, 51000 Rijeka, Croatia; e-mail: sasa.drezgic@efri.hr

\begin{abstract}
The most part of available capital owns private entities (usually multinational companies), inclined to expand their business. The impact of that is not only the maximization of their profits, but also positive effects on employment, economic growth, development of domestic financial markets and general prosperity of one country. Those are some reasons why most countries of the world actively strive to form favorable business environment, that will have positive impact to attract foreign direct investments (FDI). The aim of this paper is to examine the impact of corporate income taxation on attracting FDI flows in the EU member countries. The statistical panel analysis is conducted in the period from 1998 to 2017 for 28 EU member countries, separately for old (EU 15) and new member countries (EU13). Besides different control variables, different corporate income tax rates - statutory corporate income tax rate and effective (average and marginal) corporate income tax rates are analyzed as the independent variables in order to investigate the real tax burden of corporations and its impact on the FDI flows. It is concluded that the tax policy influences significantly the FDI flows of the corporations in the new EU member countries (that are characterized by the lower tax burden), but not as the primary factor (unlike GDP). Among the tax rates, there is the strongest influence of the effective average tax rate.
\end{abstract}

Key words: corporate income tax, FDI, EU 15, EU 13 